\title{
Antecedents of Business Students Perception on Business Social Responsibility (BSR): A Comparative Study of Bayero University Kano (Nigeria) and University Utara Malaysia (UUM)
}

\author{
Abdullahi Hassan Gorondutse \\ Phd (Candidate) School of Business Management, \\ College of Business, Universiti Utara Malaysia \\ ahgdutse@gmail.com
}

Haim Hilman

School of Business Management, College of Business, Universiti Utara Malaysia hilman@uum.edu.my

\author{
Doi:10.5901/mjss.2014.v5n20p607
}

Abstract

This study identifies and compares the antecedent of business student's perception on business social responsibility among Nigerian and Malaysian students. Part of its objectives is to examine the perception of business students in terms of importance of business social responsibility as compare to profitability, and effectiveness of social responsibility in long-term and short-term, the study review literature on the perception of business students on BSR. The factors in this study was measured using 7- point scale ranging from 1 strongly disagree to 7 strongly agree, Three hundred and fifty copies of questionnaires were administered to target the respondents from Nigeria and Malaysia. This is because UUM is the largest management university in Malaysia; likewise BUK is also the largest university in Nigeria. Two hundred and twenty copies of the questionnaire were completed and returned, 112 from students in Nigeria and 108 from Malaysian students, representing $64 \%, 62 \%$ of half of total questionnaire respectively. Giving a total responses rate of $63 \%$. The study uses linear regression, data were screened and outlier detected using Mahalonobis process. the finding reveals that there is a significant relationship between the important of social responsibility as compared to profitability in both students Nigeria and Malaysia, also the study found significant relationship between effective social responsibility and long \& short term success in both the two countries, but it was found that there is no significant relation with effective social responsibility and long term success on the part of Nigerian students, the recommendation and implications of finding were also discussed.

Keywords: Business social responsibility, business ethics, business student's perceptions, Nigeria, Malaysia.

\section{Introduction}

Business social responsibility has been regarded as voluntary activities or policies that organizations engage in for the purpose of bringing positive social change and environmental sustainability (Aguilera, Rupp, Williams \& Ganapathi, 2007). Most of such activities include donations to charities, community outreach programs, effort to improve employee diversity and reducing environmental impact (Albinger \& Freeman, 2000).

In recent years, BSR initiatives have become increasingly common as organizations compete for customers and meet the growing and dynamic expectations of their stakeholders (Matten \& Moon, 2008). As BSR activity increase and becomes a main concern universally, researches in numerous areas of management have begun to more closely examine the impact BSR on various organizational stakeholders (Balmer, 1998). These researches have among other things, examined how BSR is perceived and helps organizations develop positive ethical identities/images (Dutton and Dukerich,1991 ) in the minds of, and well-built exchange associations with, key stakeholders (Balmer, Fukukawa,\& Gray,2007;Castaldo, Perrini, Misani \& Tencati,2009; Fukukawa, Balmer, \& Gray,200 ).

Perception of business students may be varying among countries. Also there is no or little available literature in the context of the current study (UUM and BUK). However, the main objectives of the current study are as follows:

1. To identify and compare the perception of business students on importance of social responsibility as compared to profitability.

2. To identify and compare whether business student perceived effective social responsibility lead to long-term 
success.

3. To identify and compare whether business students perceived unethical behaviour of the firm lead to shortterm success.

Perception of BSR practices is helpful in setting up appropriate codes of conduct and training for expatriates to reduce potential conflicts and the likelihood of "dirty hands" occurring (Grace \& Cohen, 2005). The "dirty hands" idea states that persons, over time be likely to get their hands dirty in the absence of moral compass to provide guidance (Wong, Long \& Elankumaran, 2010).

The paper will be organized as follows: after the introduction is a literature review on Business social responsibility, Business student's perception of social responsibility is also reviewed in this context. The next section will discuss on methodology and hypothesis to be tested, next is the result discussion, and finally, conclusion and limitation for future study.

\section{Literature Review}

\subsection{Business social responsibility}

BSR has also been commonly described as a demonstration of certain responsible behaviour on the part of public and the private (business and government) sectors toward society and the environment. Business for Social Responsibility (BSR), a leading Global Business partner, in a Forum held in (2005) defined BSR as achieving commercial success in ways that respect ethical values and respect public, communities, and the natural environment. Similarly, BSR means solving the lawful, ethical, business and other responsibilities society has for firms, and building decisions that reasonably balance the claim of all key stakeholders. In its simplest conditions, it is: "what you do, "how you do it" "and when and what you say" (David, 2010).

In this Direction, BSR is viewed as a complete put of strategies, practices and activities that are incorporated into firms operations provide series, and decision making processes throughout the organisation and wherever the firm does businesses that are supported and rewarded by top management. It also includes responsibility for current and past actions as well as potential implications. The issues that signify a company's BSR focus vary by business, size, sector and even geographical region. It is seen by leadership of companies as more than a collection of discrete practices or occasional gestures or initiatives motivated by marketing, public relations or other firms advantages (David, 2010).

Similar to above, the World Business Council on Sustainability Development, (1998) described BSR as the continuing commitment by Business to behave ethically and contribute to economic development while improving the quality of life of the workforce and their families as well as of the local community and society at large. BSR is the concept that indicates an organization is responsible or accountable for its impact on all relevant shareholders (European Union, 2002).

On the other hand, significant support has been given to the concept of corporate social Responsibility. Davis (1974) argued that public visibility of corporate actions required managers to become socially responsible and that business, as an essential component of society, has a responsibility toward solving problems of social concern. Freeman (1984) defended this viewpoint and developed the Stakeholder theory. Freeman (1984) argued that firms have relationships with many constituent groups who both affect and are affected by the actions of the firm. The stakeholder theory became the dominant paradigm in business social responsibility (McWilliams and Siegel, 2001) and is the basis of the current study.

\subsection{Business students and perceived social responsibility}

The pervasive increasing concern given to corporate social responsibility has led to more research being conducted on firms and students. Business ethics has been significantly integrated in the curriculum of ethics education (Borkowski \& Ugras, 1998). However, not enough emphasis has been placed on business social responsibility. Gioia (2002) emphasis that the teaching of social responsibility has been marginalized in business curricula. He even found that the percentage of business students who believed that maximizing shareholders' value was the company's prime responsibility increased from $68 \%$ upon entrance to college to $82 \%$ by the end of the first year (Gioia, 2002).

Previous empirical research has been conducted to measure students' perception of social responsibility. Most studies also investigated demographic factors as possible explanatory variables. In order to investigate work experience as an explanatory variable in social responsibility perception, Kraft (1991) examines the relative importance of social responsibility in identifying effectiveness long-term and shor-term success among undergraduate students acting as 
potential managers. The results reveal that students viewed social responsibility as relatively unimportant compared to other determinants associated with finance, marketing and personnel (Kraft, 1991).

Kraft and Singhapakdi (1995) conducted another study to determine the relative importance of business social responsibility in effectiveness of long and short-term, the study reveals similar conclusions to Kraft (1991). The students generally believed that social responsibility was unimportant as a determinant of effectiveness. In addition, MBA students with work experience rated social responsibility as significantly more important than profitability in effectiveness compared to undergraduate students without work experience. Based on both studies, Kraft and Singhapakdi (1995) argued that ethics education and age could also be explanatory variables in perception differences between graduate and undergraduate students, since the former group of students was older and received more exposure to ethics education compared to the latter group (Kraft \& Singhapakdi, 1995).

Other studies were also conducted on students to measure their social responsibility perception and to examine work experience and age as possible explanatory variables. For example, Kumar (1995) attempted to predict the social orientation of graduate and undergraduate business students. The results showed that over three quarters of the students showed strong orientation towards social responsibility. The results also reveal that graduate student exhibited a stronger social orientation than undergraduate students. Kumar (1995) attributed this demographic difference to work experience and to the age of the respondents. He argued that adult students were less likely to change attitudes compared to younger ones (Kumar, 1995).

Research has also investigated the perception of social responsibility based on gender and college major. Regarding gender, many studies have been conducted to examine differences between male and female students in ethical perception. In a Meta analysis of these studies, Borkowski and Ugras (1998) found that most studies concluded that females judged ethical infractions more harshly than males (Paul, Zalka, Perry \& Friday, 1997) investigated gender differences in social responsibility perception. They found that female students were more sensitive Business social responsibility compared to males.

Furthermore, Burton and Hegarty (1999) reached similar conclusions. Jeffrey (1993) examined college major as an explanatory variable in students' ethical perceptions. The results indicated that accounting majors exhibited higher ethical development compared to students majoring in other business disciplines. Cohen, Pant and Sharp (1998) also examined gender and college major as determinants of college major. They concluded that accounting majors and females viewed ethically ambiguous situations as less ethical compared to other business majors and males, respectively. The previous results led to attempts to sensitize students toward the importance of social responsibility. Gordon (1998) tested whether extensive class readings and discussion make a difference in students' perception of the importance of social responsibility. The study found that students viewed social responsibility as more important to organizational effectiveness after the readings and discussion.

Similarly, The study Elias (2004) reveals that students in general perceived business social responsibility to be more important to productivity and long- term achievement of the business and less important to short-term success after media publicity of corporate scandals. In a recent study by Wong, Long and Elankumaran, (2010) on the students' perception of BSR in United State, China and India, the result found that United State and India respondent attached more importance to the non economic dimensions of social responsibility than Chinese respondents. US respondents emphasised legal obligations while the Indian respondents placed more emphasis on philanthropic activities.

\section{Methodology}

\subsection{Sample and data collection}

The population of the study consists 4000 business students in the two countries. The study employs a simple random sampling techniques, in line with sample selection formulae, which is stated as follows, (Yamane, 1967).

$$
\mathrm{n}=\frac{N}{1+N(\theta)^{2}}
$$

Where: $n=$ Sample size; $N=$ Population of the study; $e=$ level of precision.

Base on the above formulae, a representative sample size of three hundred and fifty (350) was chosen from population of 4000 business students in the two countries, with precision levels of $\pm 5 \%$ and the level of confidences is $95 \%$. The sample for this study consisted of undergraduate and graduate business students in the Universiti of Utara Malaysia and Bayero university Kano Nigeria, A survey questionnaires was developed and 350 copies of it administered in many required undergraduate business classes such as Business Policy and Strategy, Principles of Managements, and business ethics. These classes included junior (third year) students. The purpose of this selection is to get a diverse 
sample of business majors. In addition, conversations with some lecturers in universities and higher educational institutions indicated that students were exposed to the importance of business social responsibility in lower-level business courses such as Principles management and Introduction to Business. Since the purpose of this study is to determine the perception of business students on the Business social responsibility. a more appropriate sample were students who already had knowledge of business social responsibility, therefore an intermediate and upper-level sample. Furthermore, out of three hundred and fifty copies of the questionnaires distributed, a total of two hundred and twenty copies of questionnaires were completed and returned, representing 63 percent response rate.

This means that students in the sample understand the meaning of social responsibility, although not necessarily agree with its benefits. Graduate classes surveyed included required classes in MBA programs. Despite, the fact that graduate students differ significantly from undergraduates in terms of age, work experience and maturity level of understanding the importance of business social responsibility.

The study will adapt and uses Singhapakdi, Rallapall, Vitell \& Kraft,(1996) definition of effectiveness as increasing profitability, a focus on long- term success of the firm and less preoccupation with short -term success. Considering the previous research, the study expected that students will view social responsibility as positively more important to profitability and long gains. The first hypothesis to be tested as follow:

H1: Do Business students have a higher perception of importance of social responsibility as compared to profitability.

H2: Do Business students perceived that effective social responsibility lead to long term success.

H3: Does Business students perceived that unethical behaviour of the firm lead to short-term success.

\subsection{Measurement}

The study adapts and uses Singhapakdi et al. (1996). In order to measure the multidimensional nature of organizational effectiveness, the Perceived Role of Ethics and Social Responsibility (PRESOR) instrument will be used. PRESOR was developed by Singhapakdi et al. (1996). The instrument consists of 13 statements and respondents record their agreement or disagreement with each statement on a nine-point scale ranging from 1 (totally disagree) to 9 (totally agree). The instrument yields three factors as measures of effectiveness: profitability (4 statements), long-term success (6 statements) and short-term success (3 statements). But what make this research unique instead of using 9 scales this study will make use of 7 likert scale, because, according to Allern \& Rao, (2000), 7 point scale measure is well accepted in both the academic and industry research setting.

A respondent who scores high on the profitability factor believes that social responsibility is important in determining an organization profitability and competitiveness. A respondent who scores high on the long-term success factor believes that social responsibility plays a significant role in the long-term success of the organization, including overall effectiveness and employee morale. A respondent who scores high on the short -term success factor perceived that social responsibility has an effect on short-term success such as stockholders' happiness and making profits by any means.

\subsection{Goodness of measures}

Base on the previous research Singhapakdi et al. (1996), Ellias (2004) the measurement uses in this study has been tested and validated. Reliability analysis showed coefficient alphas of 0.71 for profitability, 0.57 for long-term success and 0.64, for short-term successes in the original Singhapakdi et al. (1996) study. The authors indicated that this coefficient alpha was sufficient in the exploratory stage of the survey and with a small sample. Coefficient alphas for this study were calculated and reliability was 0.80 for profitability, 0.76 for long-term success and 0.71 for short-term success. Predictive validity was also determined by Singhapakdi et al. (1996). PRESOR was correlated with ethical ideology (idealism and relativism) and a measure of socially responsible attitudes (Singhapakdi et al., 1996).

Previous studies were conducted using PRESOR. Singhapakdi et al. (1996) concluded that undergraduate and graduate business students believed that business social responsibility is important in determining effectiveness as measured by profitability, long-term and short-term success. Marta, Singhapakdi, Rallapall \& Joseph (2000) used PRESOR to conduct a cross-cultural study of business students' perception of the importance of social responsibility. The results reveal that business students from the U.S. and New Zealand had a higher perception of this importance compared to business students from India.

Similarly, Elias, (2004) used PRESOR to survey accounting practitioners, faculty and students on the perception of earnings management ethics. The results reveal that social responsibility was significantly correlated with the perception 
of earnings management ethics. Respondents who believed that corporate social responsibility was important in profitability and long-term success of the firm were more likely to view earnings management as unethical. Those respondents who viewed social responsibility to be important in short-term success viewed earnings management activities as more ethical (Elias, 2004).

\subsection{Analysis method}

Data were analyzed using SPSS 18 (PASW STATISTIC), through linear regression analysis to compare the perception of the students from the two countries.

\section{Results and Discussion}

\subsection{Demographic profile of respondents}

The demographic profile of respondents in this study shows that $66.1 \%$ of the respondents were male and the remaining $33.9 \%$ were female business students in Nigeria, while in UUM male were $50 \%$ and female also $50 \%$, this implies that the number of male business students out-numbered the female students in Nigeria, while in UUM they are equal. In terms of ages $39 \%$ of Nigerian students are less than $25 y$ ears and $71 \%$ above 25 years old, while in UUM $65.1 \%$ are less than 25 years and 34.9 were above 25 years. This means that Nigerian students are more mature than UUM. Similarly, on the ethics education, $95.3 \%$ of Nigerian students are familiar with ethics education and only $4.7 \%$ are not. At same time UUM students have $94.9 \%$ awareness about it only $5.1 \%$ are not. This implies that both Nigerian \& Malaysian are well familiar with ethics education. In terms of marital status, $58.6 \%$ of the Nigerian respondents were single and the remaining $41.4 \%$ were married, while in UUM 77.9 were single and 22.1 were married. With regards to educational level most the respondents hold Bachelor's degree representing $67 \%$ in Nigeria, followed by $11.6 \%$ of the respondents, who are Masters Degree holders, while in UUM 61.3\%, 27.4\% respectively. Furthermore, on the issue of working experiences majority of Nigerian students have $48.1 \%$ between 1-5years, 24.5\% less 1 year and 17.9\% 6-10years. Where as in UUM students $63.2 \%$ have less 1years, $26.4 \%$ 1-5years and 5.7\% 6-10years. (See table, 1)

Table 1. Demograpics Of Respondents

\begin{tabular}{lcc} 
Characteristics & Nigerian \% & Malaysian \% \\
\hline GENDER: & & \\
Male & 66.1 & 50 \\
Female & 33.9 & 50 \\
AGE: & 39 & 65.1 \\
Less 25 years & 71 & 34.9 \\
Above 25 years & & \\
ETHICS EDUCATION: & 95.3 & 94.9 \\
Yes & 4.7 & 5.1 \\
No & & \\
EDUCATION QUALIFICATION: & 13.4 & 7.5 \\
Undergraduates & 6.3 & 2.8 \\
Diploma & 67 & 61.3 \\
Degree/HND & 11.6 & 27.4 \\
Masters & 1.7 & 0.9 \\
Others & & \\
MARITAL STATUS: & 58.6 & 77.9 \\
Single & 41.4 & 22.1 \\
Married & & \\
WORKING EXPERINCES: & 24.5 & 63.2 \\
Less 1 years & 48.1 & 26.4 \\
1-5 years & 17.9 & 5.7 \\
-10years & 3.8 & 1.9 \\
11-15years & 5.7 & 2.8 \\
16-above &
\end{tabular}




\subsection{Hypotheses testing}

This study examines the antecedents of business student perception on business social responsibility. The interpretation of the hypotheses results is summarized in Table $2 a$ \& $2 b$.

Table 2a: Regression Result for Nigeria students

\begin{tabular}{|c|c|c|c|c|c|}
\hline \multirow{2}{*}{ Model } & \multicolumn{2}{|c|}{ Unstandardized Coefficients } & \multirow{2}{*}{$\frac{\text { Standardized Coefficients }}{\text { Beta }}$} & \multirow[b]{2}{*}{$\mathrm{t}$} & \multirow{2}{*}{ Sig. } \\
\hline & $\mathrm{B}$ & Std. Error & & & \\
\hline (Constant) & 2.51 & 0.49 & & 5.15 & 0.000 \\
\hline 1 NLONGTERM & 0.054 & 0.07 & 0.07 & 0.78 & 0.438 \\
\hline NSHORTTERM & 0.17 & 0.06 & 0.26 & 2.73 & $0.007^{\star \star \star}$ \\
\hline
\end{tabular}

Table 2b: Regression Result for Malaysian Students

\begin{tabular}{|c|c|c|c|c|c|c|}
\hline \multirow{2}{*}{\multicolumn{2}{|c|}{ Model }} & \multicolumn{2}{|c|}{ Unstandardized Coefficients } & \multirow{2}{*}{$\frac{\text { Standardized Coefficients }}{\text { Beta }}$} & \multirow[b]{2}{*}{ t } & \multirow[b]{2}{*}{ Sig. } \\
\hline & & $B$ & Std. Error & & & \\
\hline & (Constant) & 2.11 & 0.52 & & 4.10 & .000 \\
\hline & SLONGT & 0.15 & 0.07 & 0.21 & 2.10 & $.039 \star \star \star$ \\
\hline & SSHORT & 0.16 & 0.06 & 0.26 & 2.65 & $.009^{\star \star *}$ \\
\hline
\end{tabular}

$\mathrm{P}<0.05 ; \mathrm{T}>1.96$,

The result of regression analysis of Nigerian and Malaysian business students indicates that there is no significant relationship between perception of business students on long term than profitability from Nigerian part $(P=0.438 ; t=0.78$; $ß=0.07$ ). This is inconsistence with the result of (Elias, 2004; Wong et al., 2010). Thus, $\mathrm{H} 2$ is rejected for Nigerian students. Likewise the relationship between short term and profitability found to be significant $(P=.007 ; t=2.73 ; \beta=0.26)$. The result is consistence with the result of (Elias, 2004; Wong et al., 2010). Hence, H3 is supported for Nigerian.

However, the result of regression analysis of Malaysian business students indicate that there is significant relationships between long term \& short term than profitability $(P=0.039 ; t=2.10 ; \beta=0.21),(P=.009 ; t=2.65 ; \beta=0.26)$. Both the result is line with the study of (Elias, 2004; Wong et al., 2010), thus, H2, \& H3 Supported. For Malaysian students. In both the results it indicates that Nigerian and Malaysian students are putting much importance of social responsibility as compared to profitability ( $P=.000 ; T=5.15 ; \beta=0.33$ ). The result is consistence with (Elias, 2004). Hence, $\mathrm{H} 1$ supported. Finally, table 3, shows that R-square (R2) for Nigerian and Malaysian are 0.07 and 0.08 , respectively. This implies that $65 \%$ of variable are achieved in Nigeria and $81 \%$ was also achieved for Malaysian business students.( See table 3 ).

Table 3. R Square

\begin{tabular}{lcc} 
& $R$ Square & $R$ Square \% \\
\cline { 2 - 3 } Nigerian Students & 0.065 & 65 \\
Malaysian Students & 0.081 & 81 \\
\hline
\end{tabular}

Table 4. Model Summary

\begin{tabular}{cccccccccc} 
Model & $R$ & $\begin{array}{c}R \\
\text { Square }\end{array}$ & $\begin{array}{c}\text { Adjusted } \\
R \text { Square }\end{array}$ & $\begin{array}{c}\text { Std. Error of the } \\
\text { estm. }\end{array}$ & $\begin{array}{c}R \text { Square } \\
\text { change }\end{array}$ & F Change df1 df2 & $\begin{array}{c}\text { Sig. F } \\
\text { Change }\end{array}$ \\
\hline Nigerian & 0.26 & 0.07 & 0.05 & 0.79 & 0.07 & 3.78 & 2 & 109 & 0.03 \\
Malaysian & 0.28 & 0.08 & 0.06 & 0.70 & 0.08 & 4.51 & 2 & 103 & 0.01 \\
\hline
\end{tabular}

\section{Conclusion, Managerial Implications, Limitations and Suggestion for Future Research}

The findings of this study revealed that there is a significant positive relationship between: the importance of social responsibility as compare to profitability, the study also found a significant relationship between effective social responsibility and long and short term success for both Nigerian and Malaysian business students. Meanwhile, the study found that there is no significant relationship between effective social responsibility and long term success on the Nigerian students.

The implication drawn from the direct effect of perception of business students which indicate much importance in long term \& short term than profitability. The findings from this study will be useful for the managers in making better 
business decision making in relation to business social responsibility, it also enhances the literature in the context of Business social responsibility in other words it goes along with theory of BSR. However, the findings in the study have been supported by previous studies. It must be noted that this study have some methodological limitations. First, the data for the study were mainly collected from higher institutions Kano metropolis and UUM business students. Thus, the findings of the study cannot be generalized to the entire business students in Nigeria as well as Malaysian. In order to overcome these limitations, future studies should consider the possibility of increasing the sample size by including more students in their studies. In addition, future studies should employ a longitudinal research design, so that the direct effects of the independent variables on the dependent variables could be concluded.

\section{References}

Aguilera, R. V., Rupp, D. E., Williams, C. A., \& Ganapathi, J. 2007. Putting the S back in corporate social responsibility: A multi level theory of social change in organizations. Academy of Management Review, 32, 836-863.

Albinger, H. S., \& Freeman, S. J. 2000. Corporate social performance and attractiveness as an employer to different job seeking populations. Journal of Business Ethics, 28, 243-253.

Allen, M. \& Rao, T. R. 2000. Analysis of customer satisfaction Data, ASQ Milwankee: Quqlity press.

Balmer, J. M. T. 1998. Corporate identity and the advent of corporate marketing. Journal of Marketing Management, 14, 963-996.

Balmer, J. M. T., Fukukawa, K., \& Gray, E. R. 2007. The nature and management of ethical corporate identity: A commentary on corporate identity, corporate social responsibility and ethics. Journal of Business Ethics, 76, 7-15.

Borkowski, S. C. \& Ugras Y. J. 1998. Business Students and Ethics: A Meta-analysis, Joumal of Business Ethics 17, 1117-1127.

Business for social responsibility (BSR), 2005. Introduction (Online) available at www.bsr.org.(Accessed March 2005).

Burton, B. K .\& Hegarty, W. H. 1999. Some Determinants of Student Corporate Social Responsibility Orientation, Business and Society 38, 188-206.

Castaldo, S., Perrini, F., Misani, N., \& Tencati, A. 2009. The missing link between corporate social responsibility and consumer trust: The case of fair trade products. Journal of Business Ethics, 84(1), 1-15.

Cohen, J. R., Pant L. W. \& Sharp, D. J. 1998. The Effect of Gender and Academic Discipline Diversity on the Ethical Evaluations, Ethical Intentions, and Ethical Orientation of Potential Public Accounting Recruits, Accounting Horizons 12, 250270.

Dutton, J. E., \& Dukerich, J. M. 1991. Keeping an eye on the mirror: Image and identity in organizational adaptation. Academy of Management Journal, 334(3), 517-554.

Elias, Z. R. 2004. An examination of Business Students Perception of Corporate Social Responsibilities Before and After Bankruptcies, Journal of Business Ethics, 52, 267- 281.

Elias, R. Z. 2002. Determinants of Earnings Management Ethics among Accountants, Journal of Business Ethics 40, 33-45.

European Commission E.U. 2002. Promoting a European framework for corporate social responsibility (Green paper), Brussels

Fukukawa, K., Balmer, J. M. T., \& Gray, E. R. 2007. Mapping the interface between corporate identity, ethics, and corporate social responsibility. Journal of Business Ethics, 76, 1-5.

Gioia, D. A. 2002. Business Education's Role in the Crisis of Corporate Confidence,Academy of Management Executive 16, 142-144.

Gordon, I. M. 1998. Enhancing Students' Knowledge of Social Responsibility Accounting, Issues in Accounting Education 13, 31-46.

Jeffrey, C 1993. Ethical Development of Accounting Students, Non-Accounting Business Students, and Liberal Arts Students, Issues in Accounting Education 8, 86-96.

Kraft, K. L. 1991. The Relative Importance of Social Responsibility in Determining Organizational Effectiveness: Student Responses, Journal of Business Ethics 10, 179-188.

Kumar, K. 1995. Ethical Orientations of Future American Executives: What the Value Profiles of Business School Students Portend, SAM. Advanced Management Journal 60, 3238.

Marta, J. K. M., Singhapakdi, A., Rallapalli, K. C., \& Joseph, M.:2000. 'Moral Philosophies, Ethical Perceptions and Marketing Education: A Multi-country Analysis', Marketing Education Review 10,

Matten, D., \& Moon, J. 2008. "Implicit" and "explicit" CSR: A conceptual framework for a comparative understanding of corporate social responsibility. Academy of Management Review, 33(2): 404-424.

McWilliams, A. and D. Siegel: 2001, 'Corporate Social Responsibility: A Theory of the Firm Perspective', Academy of Management Review 26, 117-127.

Paul, K., Zalka, L. M.,Downes, M., Perry, S. \& Friday, S. 1997. U.S. Consumer Sensitivity to Corporate Social Performance', Business and Society 408, 408- 419.

Singhapakdi, A.,Vitell, S. J., Rallapalli, K. C., \& Kraft, K. 1996. The Perceived Role of Ethics and Social Responsibility: A Scale Developmen, Journal of Business Ethics 15, 1131-1140.

Singhapakdi, A., Kraft, K. L.,Vitel, S. J. \& Rallapalli, K. C. 1995. The Perceived Importance of Ethics and Social Responsibility on Organizational Effectiveness: A Survey of Marketers', Journal of the Academy of Marketing Science 23, 49-56.

World business council for sustainable development (WBSSD). 1998. Corporate Social responsibility: The WBCSD'S Journey. Greneva

Wong, A., Long, Fu., \& Elankumaran, S. 2010. Business Students Perception of Corporate Social Responsibility: The United States, China, and India. Corporate Social Responsibilty and Environmental Management, 17, 299-310.

Yamane, T. 1967. Statistics: An Introductory Analysis (2nd ed.). New York: Harper and Row. 